\title{
NARRATIVES AND DILEMMAS OF LOCAL BUREAUCRATIC ELITES: WHITEHALL AT THE COAL FACE?
}

\author{
FRANCESCA GAINS
}

The worlds of local bureaucrats are under researched and under theorized compared with those of civil servants in core executives. Yet local bureaucratic elites, sitting as they do between central states and localities, are key actors in governance networks. In England, the role and responsibilities of local bureaucratic elites has been transformed since the days of professionalized officers heading departmental structures reporting to committees, firstly by NPM and politicization in the 1980s and 1990s and, more recently, by political management reform introducing a separation of powers. Drawing on interviews in 15 local authorities, this paper examines the changing narratives and dilemmas of local government elites. In particular it explores, but argues against, early expectations that the creation of an elected executive, with considerable devolution of decision-making responsibilities to individual cabinet member councillors, has meant a move closer to the logics of the 'Whitehall mandarin' tradition by local government chief officers.

\section{INTRODUCTION}

Across Europe there has been a wave of reform of the operating environment of local bureaucrats, reforms which share a focus on strengthened leadership along with the expectation of partnership working (Borraz and John 2004; Denters and Rose 2005; Gains 2007). Yet compared to the literature on national civil servants (see, for example, Peters 1997; Weller et al. 1997; Richards 2007), the world of local government officers is relatively under researched. More academic attention is given to researching local political leadership and parties and more recently partnership working (Sullivan and Skelcher 2002; Goss 2003; Stoker 2003; Copus 2004; Sullivan 2007). In part this reflects the huge variation in the roles and tasks of local bureaucrats. Generalization of their impact on power relations, decision making and service delivery in a locality and across local government is difficult to sustain.

This paper seeks to explore the governance traditions of local government bureaucrats, the changing resource exchanges and consequent power dependencies they operate with, and the extent to which they share the narratives and dilemmas faced in navigating contemporary roles and relationships. The material presented here is based on over 100 interviews in a representative range of 15 local authorities with chief executives, leaders, portfolio holders, chief officers and service heads, non executive party leaders and officers serving scrutiny as well as local stakeholders. The focus here, then, is on elite actors and the political-bureaucratic relationship between the most senior officers and leading councillors.

The analytical approach taken here will first be discussed and can be described as an 'institutional interpretivism' denoting a de-centred approach to understanding how actors both construct and interpret their agency, given material changes in institutional arrangements within which they operate. The key argument is that there will be a diverse dependency between officers and their political counterparts, which will vary according to the allocation of political, informational and operational resources. These differing

Francesca Gains is in the Department of Politics, School of Social Sciences, University of Manchester. 
material circumstances will form the context within which local actors interpret their conduct, leading to differing narratives and dilemmas of change. A second section reviews the literature on the changing traditions, inheritances and practices of local governance and relates these changed beliefs and actions to the political resources held by elite actors. There follows a section reviewing the introduction of separate political executives and highlighting three dilemmas anticipated in the literature by this reorganization of rules, roles and relationships. This includes the expectation that the narratives of senior local bureaucrats would increasingly emulate those of national senior civil servants as institutional changes created the situation for a closer and more exclusive working relationship with a political principal. A final section will explore these three anticipated dilemmas flowing from the contemporary governance arrangements. It will also present the narratives used to describe and interpret these dilemmas, firstly negotiating role boundaries, secondly managing tensions between central and local accountabilities, and thirdly balancing the needs of executive and non executive politicians.

In the conclusion, it is argued the varied narratives of senior bureaucrats in local government, although not static, are linked to their institutional, constitutional, political and personal circumstances. In authorities with stable political control and strong leadership structures, senior officers clearly are working much more closely with a smaller group of leading councillors. As with their Whitehall counterparts, these relationships work best when there is a shared understanding of the political legitimacy of the elected politicians and informatory advantages held by bureaucrats. Overall, however, a cadre of local 'Sir Humphreys' does not appear to be developing and it is argued that this is unlikely, given two traditions deeply embedded in the local government: that of serving the whole council; and that of more transparent delegation of decision making.

\section{DYNAMIC DEPENDENCY AND INSTITUTIONAL INTERPRETIVISM IN LOCAL POLITICAL BUREAUCRATIC RELATIONSHIPS}

This section draws on both historical institutionalist and interpretivist ideas and literature to develop a heuristic framework of analysis to explore the de-centred narratives and dilemmas of local political elites. Wilson and Game (2007) suggest that hitherto there have been three approaches to the study of local political bureaucratic relations. A traditional and constitutional perspective sees that politicians decide and officers implement policy, a view which, although providing an unrealistic empirical portrayal, highlights the normative and legalistic 'rules of the game' and the political and authoritative resources which elected politicians hold. A second more realist perspective suggests that officers really dominate decision making and that because of their technical expertise and the advantage of permanency, their ability to set the agenda is dominant (Gyford et al. 1989, p. 95). However, this view fails to acknowledge both the possibility and the reality of political direction and the politically divergent paths taken in some local authorities. The value of this perspective is that it highlights the informational and administrative resources which officers have and which elected members may not share. A third 'dual-elite' position argues that a coalition of senior members in the ruling group and senior officers dominate the decision-making processes in a local authority (Saunders 1980; Green 1981). There are problems in this latter approach however in that it assumes a shared agenda within and between local bureaucratic and political elites which may not always be the case (Gyford et al. 1989, p. 116). It may also underestimate the influence of backbench councillors, the power of the party group, and the degree of unity of policy perspectives 
within departments (Byrne 1992, pp. 212-13). The problem with the traditional, realist and dual-elite approaches is that although each one of them may reflect the position in one authority at a particular point of time, they cannot capture the dynamic and variable power relationships which can be found across local government either as a whole or over time (Gains 2004a).

It is argued here that understanding the political bureaucratic relationship in local governance settings requires a 'dynamic dependency' analysis (Gains 2004a). In part this approach adapts some of the literature adopted to theorize about civil servants in core executives (see Thain and Wright 1995; Rhodes 1997; Smith 1999; Richards and Smith 2002; Gains 2004b), suggesting that each actor (or group of actors) holds resources which are exchanged to achieve policy goals. Typically, politicians hold the key resources of political authority, granting them legitimacy to act; they also have fiscal authority to control the purse strings or financial resources. Administrators hold informational resources, the necessary professional and technical skills in a policy area, and the organizational knowledge or logistical understanding of policy delivery. The exchange of resources necessary to make and deliver policy takes place, then, in power dependent networks operating within institutionalized settings. A similar organizational analysis of local government is developed by Leach et al. (1994, p. 60). A dynamic dependency approach illustrates historical institutional antecedents in suggesting that the institutional arrangements - roles, rules and resources - are key in setting a context within which local bureaucratic actors act. The idea of dynamic dependency provides an understanding of why the type of relationship found in each local authority might vary since the institutionalized understandings within which actors operate will be different in each setting as well as being historically informed. The extent of the resource exchange will vary and depend upon, for example, the strength of the political resources a council leader can command, the strength of the party group, or the degree to which a service head can dominate policy-making through technical or professional knowledge.

This 'dynamic dependency' analysis also draws on an interpretivist or social constructionist perspective in suggesting that actors interpret how to act (Yanow 1996; Bevir and Rhodes 2003; Richards and Smith 2004; Richards 2007). It is argued that the interpretations of local bureaucrats are informed not only by the formal legalistic and operational 'rules of the game', which provide an action orientation supported by resource flows, but also by the internalized and informal perceptions by actors of appropriate role behaviour and how to operate. The power potential of actors is linked to group dynamics, and the perceptions, skills and tactics of individuals seeking to achieve personal goals. The advantage this approach has over a dual elite concept is that it doesn't assume a shared world view or agenda - although where there are shared goals, as Stewart points out, a shared perspective does tend to develop over time (2000, p. 235). Thus varying interpretations of the appropriate roles and relationships can be anticipated. However, there is likely to be patterning and this can lead to shared narratives of change within 'communities of meaning' (Yanow 1996). For Bevir and Rhodes, when several of these narratives cluster, they form a 'group of ideas', 'a set of beliefs and habits' which can constitute a 'tradition' inherited by individuals but not determining their future actions and beliefs since it is not possible assume a world view which can be read off from the material circumstances (2003, p. 33). To use Hay's terms, these material contexts, although they may be 'conduct shaping', are not 'conduct determining' (Hay 2004). Bevir and Rhodes stress that traditions are not fixed - they vary over time and across communities of meaning. When new ideas challenge traditions this creates dilemmas for actors and requires new 
narratives of change (Bevir and Rhodes 2003). Methodologically, therefore, an interpretivist approach requires a de-centring of the research focus of empirical analysis to capture actors' own interpretations of how they read and then shape the context in which they conduct themselves.

However, those wishing to engage with interpretivist methodologies can turn to differing disciplinary, epistemological and ontological starting points (for discussions of varieties of interpretivism, see Bevir and Rhodes 2003, 2006a; Richards and Smith 2004; Finlayson 2004; Clarke and Gains 2007). Within the political literature on interpretivism there are current ontological debates over the analytical and temporal sequencing of 'past agential activity' and the extent to which 'traditions' are related to material circumstances or whether this leads to a reification of the context within which narratives and dilemmas arise (McAnulla 2006; Bevir and Rhodes 2006a, b; Bevir 2007; Richards 2008, p. 227). Bevir and Rhodes call for greater clarity in what is meant by practices which ontologically speaking constrain the agency of political actors (Bevir and Rhodes 2006b, p. 7). Here, what might be called an 'institutional interpretivist' approach, guides the analysis, one which sees that changed material circumstances in the 'situated context' in which strategic actors operate (Hay 2004) often require changed practices, creating differing narratives of change and consequent dilemmas (Bevir and Rhodes 2003). The adoption of an institutional perspective to the interpretivism offered here is to denote an ontological acceptance that there are external realities which create a structured context within political and bureaucratic actors interpret their agency (Richards and Smith 2004; McAnulla 2006). However, in seeking to avoid the reification of the material context, the analysis tries to be explicit about the kinds of practices, within overarching traditions, which can lead to new narratives and dilemmas and ultimately to new traditions of governance at the local level. The section that follows draws on the idea of dynamic dependency and institutional interpetivism to examine the evolution of the officer role in the post war period. The focus is on the institutional rules and consequent role understandings shared by the officer elites and on the resources held as well as the skills and tactics open to senior bureaucrats.

\section{TRADITIONS, INHERITANCES AND CHANGE IN LOCAL GOVERNANCE}

Key traditions in local government in the UK include the following (Gyford 1985; Stewart 2003):

- its historically departmental nature;

- its hierarchical nature;

- the understanding that officers serve the whole council;

- officers' neutrality.

Until the mid 1980s, each local authority was made up of a group of departments delivering functionally defined and professionally based services. Each of these vertically segmented departments was also horizontally segmented into a tiered hierarchy headed by senior administrators called chief officers who had been promoted from within the dominant profession. Stewart describes the position of chief officers at this time saying 'the department spoke through the chief officer' and the organizational structure during this era could be accurately described as a professional bureaucracy (Stewart 2000, pp. 352, 52). Local authority chief officers were powerful in their professional domains and operated autonomously (Leach and Percy-Smith 2001). A small central bureaucracy was run by the 'town clerk' who operated amongst the chief officers as primus inter pares (Stewart 
2000, p. 54). Members of this top tier of officials were not as geographically bounded in their careers as were either officers lower down the hierarchy or local politicians. Their career paths took them to several authorities and provided what is described as a 'cosmopolitan' outlook (Gyford 1976, p. 25). Hence their allegiances and world views were seen to relate to national actors and professional, rather than purely local, perspectives.

These local bureaucratic elites shared some characteristics with their national civil servant counterparts: for example, the presupposition of neutrality (Gyford 1976, p. 24); the understanding that their role is to implement and not to make policy (Kerley 1994, p. 176); and of being guided by a public service ethos (Pratchett and Wingfield 1996; Goss 2003). There are crucial differences, however: whereas civil servants primarily operate to a specific minister, local government officers are charged with serving the whole council and, historically, were more likely to have political contact with a range of councillors of all political persuasions than were their national counterparts. The second key difference is that unlike the generalist civil servant counterparts most white collar workers in local government had a professional specialism providing them with the key resource of professional or technical knowledge which challenged the political authority held by councillors (Gyford 1976, p. 25; Byrne 1992; Gyford et al. 1994, p. 96; Stewart 2000, p. 200). As well as informational resources, chief officers had a temporal advantage in that they had time to commit to understanding a policy area and to developing policy in a way the generally part-time and non-professional councillors did not (Chandler 2001, p. 166).

The impact of Thatcherism on local government added to these historical 'inheritances' of shared world views or traditions. Such impacts included the introduction of New Public Management (NPM) interventions designed to improve economy, efficiency and effectiveness, and the reassertion of political authority in response from the Labour Left, creating a more politically assertive operating environment (Leach et al. 1994, p. 152). In the UK, local government NPM prompted interventions that included a cap on revenue raising and spending, the introduction of private sector competition through Compulsory Competitive Tendering (CCT), and an emphasis on decentralization and partnership, alongside emerging strategic and corporate management solutions heralded by the Maud and Bains Committees (see Stoker et al. 2003). Rate capping, as well as the fundamental squeeze on resources flowing in from central government, represented a challenge to the assumptions of growth and the dominance of professional solutions to public policy problems and provision. As a result, chief officers found themselves managing reductions in services (Leach and Percy-Smith 2001, p. 162). For officers working at the strategic level, new skills of co-ordination and consultation with private and voluntary partners were needed and a more outward-looking stance became necessary (Wilson and Game 1994; Stoker 2003, p. 39).

The Widdecombe Inquiry was set up to examine politicization in local government. Its report identified the huge variety of practices adopted in authorities and sought to regularize and codify the formal roles and relationships between members and officers (Widdicombe 1986). The role of the party group was legitimized and recognized while the neutrality of officers was strengthened through the explicit ban on political activity for senior officers. In addition, the report enshrined the principle of political balance in local government committees. Both NPM and politicization impacted on the role and power of officers (Young 1987; Laffin 1990; Leach et al. 1994, p. 158). Out of this era of 'reappraisal', the role and tasks of chief officers changed, together with their relationships with elected members. The current genre of senior officers are strongly influenced by the Widdecombe recommendations and the acknowledgement of formalized politics in local government. 
In 1997, as New Labour assumed power, the contemporaneous bureaucratic elite was on the whole less professionally bounded - but they held far more developed managerial skills than their predecessors. Senior officers were accepting of the need to work to a strategically identified corporate agenda under the central direction of the chief officer and, where the local authority was not the sole provider, to work in partnership with a plethora of other organizations. As Goss noted, managerialism 'changed how people in public agencies think about themselves' (2003, p. 141).

The balance of power - or power dependency - between members and officers had also shifted in that the legitimacy and political resources of elected members had increased. On the officer side, there was a decline in professional specialism as a source of legitimacy, albeit differentially felt in different functional areas, and an increase in a new type of managerial professionalism, one that was far more corporate and strategic (Laffin and Entwistle 2000; Ackroyd et al. 2007). As before, the variety of differing power relationships amongst authorities of different types and different political arrangements was still large (Travers et al. 1997; Stewart 2000). Overall, however, officers still retained the crucial resources of time, specialist knowledge and organizational capacity.

The incoming New Labour government of 1997 accelerated the managerialism and partnership focus in local government already established during the Thatcher and Major Governments (Rhodes 1995; Travers et al. 1997). Two White Papers set out a range of reform measures - collectively known as the Local Government Modernisation Agenda (LGMA) - which expressed attitudes towards the role of local government in delivering improvements in public services, crucially outcomes, that were both ambitious and ambivalent (Newman 2001; Stoker 2003). The establishment of a centrally driven performance management system of local public service agreements and a comprehensive performance assessment (CPA) process has demonstrated what Stoker calls governmental 'steering centralism', where national objectives and targets govern local direction (Stoker 2003). Paradoxically, an agenda of evidence-based policy experimentalism and a focus on joined-up government to address difficult issues, has led to a new localism partnership agenda of networked governance arrangements (Sullivan and Skelcher 2002; Stoker 2003). Against this context of tradition and change in the operating environment of local bureaucratic elites, a fundamental change in the 'political' management arrangements of local government mirrored simultaneous centrifugal and devolutionary tendencies of the 'performance' management agenda. The section that follows sets out the formal and informal changes brought about by political management reform and identifies three potential tensions for the role and activities of local political elites arising from constitutional change in English local government.

\section{POLITICAL MANAGEMENT REFORM UNDER NEW LABOUR}

The Local Government Act 2000 introduced a separation of powers in English local authorities to create a separate political executive of either an elected mayor or an indirectly elected leader, and, in both cases. a small cabinet of executive councillors with decisionmaking powers. The Act permitted greater delegation of decision making to officers and area committees (see Stoker et al. 2004, 2007). Non-executive councillors gained a new scrutiny role to challenge executive decision making. The 2000 legislation and guidance says very little about how these radical changes would affect the officer structure and merely highlights the expectation that officers will remain responsive to the whole council (ODPM 2001, para 8.2). In the academic and practitioner literature, however, the new 
political management arrangements were thought to hold the potential to create tensions in three areas, as outlined below.

Firstly the new arrangements were anticipated to create a blurring of roles. One argument made as the new constitutions were being developed was that the performance and political management reforms of the LGMA have the potential to create a stronger national framework for local bureaucratic activity whether it be ensuring the fulfilment of national performance targets or forming and operating in local partnerships leading to the development of two new roles for officers (Fox et al. 2002). A 'council custodian role' is centrally located, internally orientated, strategic in focus with keen appreciation of the national agenda. A 'community enabler' role is more outward looking, community based and concerned with external relationships. The 'community enabler' role was envisaged to create the possibility for tensions between officers and the new political executives as officer partnership working could undermine the leader, mayor or executive councillor role in providing community leadership ((Fox et al. 2002, p. 23; Goss 2003, p. 124).

Similarly, officers acting as 'council custodians' of national policy objectives potentially creates role confusion in dealing with the newly enfranchised political executives. The simultaneous strengthening of the national performance framework and local political leadership was thought to exacerbate conflicting political loyalties for officers, leading to a second tension: that of officers facing the dilemma of being responsive and accountable to both national and local political leaders (Gains 2004a).

Finally, early commentaries on the reforms also expressed caution about the way in which a separation of powers could work with the tradition of officers serving the whole council. It was questioned whether it would be possible for officers to be 'two-hatted' and serve both executive and scrutiny politicians (Fox and Leach 1999; Skelcher and Snape 2001; Snape et al. 2002, p. 81; Fox et al. 2002). For Stewart, the implication of creating separate executive structures would lead to an officer ethos akin to the civil servant modus operandi where loyalty is to individual ministers and confidentiality ensured 'If structures are adopted drawing on parliamentary models it is no surprise if officers come to regard themselves as no more responsible to the whole council as civil servants are to Parliament' (2003, pp. 88-9). In constitutions which provide specialized officer units these can be seen as a source of organizational legitimacy for the scrutiny officer function, creating a separate set of resource exchanges and dependency relationships between scrutiny officers and non-executive members. However, while addressing the issue of two-hattedness, the new scrutiny officer role raises the question of the unified career path of local government with the possibility of officers forced to choose between a career servicing the scrutiny function and working to executive.

In making an assessment of how this reform has changed the way in which local bureaucratic elites work, and the way they think about their work, it is possible to identify general overall changes in the formal and informal rules of the game, roles played, and resource exchanges, all of which have created a changed networked governance narrative for the exercise of local bureaucratic leadership. In the language of diverse dependency, the LGMA enhances the potential informatory and delegated decision-making legitimacy of officers and reduces their accountability to the whole council while at the same time enhancing the political legitimacy of leaders and executive councillors and their privileged access to the informatory resources provided by officers. However, the degree of dependency, nature of the ensuing relationship, and local 'communities of meaning' are likely to be extremely varied, leading to differing narratives and dilemmas of change in localities. There now follows an exploration of the dilemmas described above which were 
anticipated by early interrogations of political management reform. It uses an interpretive methodology to de-centre the focus to examine the emerging narratives of local bureaucratic elite actors and in particular the dilemmas they face in different contexts. In particular the question of whether local bureaucrats are operating with the logic of their national counterparts is addressed.

\section{THE EMERGING NARRATIVES AND DILEMMAS OF LOCAL BUREAUCRATIC ELITES}

\section{Managing the blurring of boundaries}

The delegation of decision making to a smaller group of executive councillors and to officers has clearly created the conditions for a blurring of roles and responsibilities. As mentioned above, executive members and leaders are increasingly permitted to take decisions alone. The most recent survey of new constitutional arrangements in authorities showed that in just over one-third of leader cabinet authorities the leader can take decisions alone and nearly two-thirds permit executive councillors to take decisions alone. A third of executive councillors write their own reports and most present reports at cabinet. Over 8 out of 10 authorities permitted delegated decisions to be taken by officers in their constitutions and two-thirds of officers have taken a decision alone. Officers report spending more time working with executive councillors and especially partner organizations (Stoker et al. 2007). A recent Solace investigation into managing in a political environment described the area where executive councillors and senior officer have to operate as a 'zone of interaction' (Solace 2005) and this relationship was described by the then Office of the Deputy Prime Minister (ODPM) as 'a subtle and dynamic partnership' (ODPM 2005).

However, despite the potential for clashing roles, both officers and executive councillors report liking the reforms (Stoker et al. 2004). In many authorities this relationship is reported to work well, with all actors comfortable with blurred boundaries. One chief executive in a mayoral authority commented wryly 'the chief executive has to manage the bits the mayor is not interested in!', while the mayor acknowledged 'I cross the management line for little things - but I know where the line is'. Here the chief executive felt that the line between that role and the mayoral role was not clear but was understood 'it's all about relationships'. In a Conservative leader cabinet county, with a long-standing leader and excellent CPA score, the chief executive provided another example of a comfortable relationship, albeit one where a clear boundary between political and bureaucratic roles were being overtly emphasized. Here the authority had voted to exceed its capping limit; the chief executive explained: 'officers have given advice, if the decision makers go against it that's a political decision. We've fulfilled our legal obligation - on their heads be it'.

In other local authorities, this relationship was not reported as quite so comfortable - an executive member in a hung leader cabinet (where there was no one political party in overall control) of a unitary authority agued that roles were clear 'with a clear boundary' but added, somewhat ambivalently, 'it's good to look over your shoulder'. The monitoring officer in a labour leader cabinet district authority complained that 'managers used to be left to get on with it, now politicians get too much involved in things they don't know about and don't understand the implications'. During the very early days of a newly established mayoral authority the officers were described as being 'in shock'. Perhaps the most public breakdown of the relationship between leader and chief executive was that which occurred in a Liberal Democrat leader cabinet metropolitan authority 
where it was reported the chief executive had overstepped the political boundary and that the leader used officer structures inappropriately (Smulian 2005).

Despite the possibility of the 'community enabler' role to create tensions between elected and officer leadership, partnership work undertaken by officers was not described as adding to the blurring of boundaries. Officers spend more time on partnership work (14 hours a month on average) than on working with executive councillors and the reported time has doubled since 2003 (Stoker et al. 2007). One cabinet member in a hung unitary authority suggested: 'officers do it, executive members are just figureheads'. There are clearly different experiences. In mayoral authorities, for example, the mayor has a clearer mandate for partnership work. As one mayor explained: 'I have no power, just influence, they take the calls because I have the mandate'.

What appears to help overcome the potential for blurred boundaries in all authorities is the clear delegation of decision making between officers and executive members, with a schedule of delegated decisions published in all councils' constitutions. Also described was a shared incentive for cooperation provided by the performance assessment framework, with both officers and executive members adopting the 'council custodian role'. The pressing dilemma for both officers and executive councillors is to get the best result for the locality. As one portfolio holder in a hung leader cabinet unitary authority suggested, 'you got to watch the boxes'. The chief executive in this authority stressed that both she and the leader want the same things: 'a successful district'. In a hung county authority the leader said 'all officers and cabinet members want excellence in the CPA' and the chief executive was explicit, 'if the relationship breaks down the CPA breaks down'. An executive member in a mayoral authority said 'I want to be an excellent authority every time'.

The impact of the new political management arrangements on the relationship between offices and political leaders varies. In a Labour metropolitan leader cabinet, authority views were expressed that the creation of cross-cutting portfolios had diminished the professionalized power of service heads. The monitoring officer here argued that there are now 'no empires'. However, despite the increase in political authority and decisionmaking capacity granted to leading councillors, in many places officers still have informational advantages and considerable overt, transparent, delegated decision-making powers. In one Conservative leader cabinet county authority, the leader described the executive councillors as 'gifted amateurs'. In another Conservative leader cabinet county authority, the chief executive felt local government was still 'officer/profession led, member input is still the lay persons view'. In a Labour metropolitan leader cabinet authority the chief executive argued 'modernization gives officers more power' and suggested that the focus on national priorities had created what he called 'corporate parenting'. This was especially evident when hearing views on how officers sought to manage the tensions created between central and local policy agendas.

\section{Managing central local policy accountabilities}

To a far greater extent than is the case with national civil servants, local senior bureaucrats have to manage the dilemma of being responsive to two sources of political authority and must manage accountability to both central and local elected politicians. The way in which officers describe their 'Janus-facing' activities is set out elsewhere (Gains 2004a). Officers describe the tension between supporting a locally strengthened executive in a context where central control of policy and performance is increasingly exercised. A Chief Finance Officer (CFO) in a Labour unitary leader cabinet authority explained: 'officers 
have driven a corporate management approach, members don't see what they have to achieve in these terms - officers have to marry the priorities up and fit national priorities to the national context'. The scrutiny officer here suggested, 'there can be a lot of negotiation about the interpretation of national priorities - we work with members to get them on board and work with us'. The latter demonstrates how skilled and experienced officers describe their role as enabling the exercise of leadership. A chief executive in a Conservative county leader cabinet authority suggested, 'you have to strike a balance between leading them in the right direction and not setting it up'.

One tension in this respect is the situation where, when there is a lack of clear leadership, officers have to drive through central agendas. In a hung leader cabinet county authority the role of the monitoring officer had been to lead the process of setting the new constitutions. As a colleague explained, 'he did more than broker, there was a vacuum and he had to fill it'. In hung and balanced authorities and authorities with strong party structures, the dilemma for officers is not so much balancing the central and local executive agenda, it is bridging a shared 'corporate custodian agenda' with non-executives and party groups. A CFO in a hung unitary leader cabinet authority described the process he went through as getting 'political buy in for the budget'. All officers are clear however that the central agenda is the one which carries greater legalistic and financial weight. In a Labour unitary leader cabinet authority the CFO explained the rules of the game central government has 'ultimately got the purse strings and we need to fit local priorities to the national context'.

\section{'Serving the whole council'}

There are differences in how officers view the potential for closer relationships with executive councillors to create a democratic deficit in their relationship with non-executive officers. A survey of officers conducted in 2005 suggested that three-quarters of officers did not feel there was a problem of wearing two hats (Stoker et al. 2005). In interviews, most senior officers stoutly defended their ability to serve the whole council. CFOs are the group with most robust views, possibly given the fact that for some time they have had a legal responsibility for advising all parties on the budget development and have had longer to develop strategies for delivering what one officer in a hung unitary leader cabinet authority described as 'frank and fearless advice to all parties'.

In some authorities, tensions were reported, particularly related to the newly emerging scrutiny processes, with non-executive councillors suspicious that officers were moving away from serving the whole council. In a hung county leader cabinet authority the scrutiny officer felt it was difficult to have a unified structure: 'the politicians think the officers can't be two-hatted'. In a small district Labour leader cabinet authority, the chief executive felt, 'it's difficult for officers, they get blamed and take the stick for executive decisions - members have a go'. In this authority, overview and scrutiny activity was known as 'over-screw and mutiny'. The chief executive of a hung alternative arrangements district authority felt 'time pressures' reduced the extent to which officers could support scrutiny. In a Liberal Democrat unitary leader cabinet authority, the monitoring officer felt in the early days: 'officers were unsure how to respond to scrutiny and how much to support it'. As a scrutiny officer in another Liberal Democratic metropolitan leader cabinet authority put it: 'officers know where the bodies were buried'.

However, in only one authority were these tensions felt to be leading to an officerexecutive councillor relationship akin to that of minister and civil servant. The CFO in this unitary Labour leader cabinet authority felt scrutiny councillors were not appreciating 
that portfolio holders made decisions and officers felt they had to go and protect their portfolio holder, providing a 'double act' akin to that of a national civil servant. The monitoring officer in this authority felt officers there had to be 'on their guard' when attending scrutiny and that there was a feeling that 'if you want to get on in life you need to impress your lead member'.

The dilemma related by most officers over their changing relationship with executive and non-executive councillors was not that the creation of executives has devalued the idea of serving the whole council and led to the creation of local 'Sir Humphreys', but that, with the demise of the committee structure, there comes the loss of a training ground for developing political management skills (Stoker et al. 2004). Narratives around the development of scrutiny roles and processes revealed how the twin dilemmas of maintaining the tradition of serving the whole council and providing political skills for younger officers could be addressed. An executive member in a hung unitary leader cabinet authority suggested scrutiny could be used as a 'nursery' in this respect and this sentiment was expressed elsewhere.

Two mayoral authorities, both with separate scrutiny units, presented the most robust picture of scrutiny roles and political executive independence. In one, the scrutiny officer felt scrutiny should be focused on the evidence and officers shouldn't have to defend portfolio holders, 'if a portfolio holder agreed a recommendation then they need to own it'. For this officer, colleagues attending scrutiny had the chance to develop their political skills. Managing scrutiny is 'down to the officer's own professionalism - there is no reason in the system to create a problem, if you are clear about your role'. In another mayoral authority, scrutiny officers told stories of an occasion when officers from a service area had failed to attend a scrutiny meeting and had been 'hauled in front of the mayor'. The scrutiny officer explained that the non-attending service officers had not recognized the authority that scrutiny carried: 'they don't realize the pecking order, scrutiny had to send out the cultural message that members run the council and officers serve'. For this officer, confident that the mayor was supportive of the scrutiny process, 'scrutiny helps to remind middle managers of the food chain in a political environment'.

The creation of officer support for scrutiny is described as assisting in negotiating these new roles and relationships. The role of scrutiny officer is a developing one, and in some cases is recognized as a useful part of the management career path. One scrutiny officer in a Labour metropolitan leader cabinet authority with a well-resourced scrutiny unit explained she had been worried that moving into scrutiny 'was a black hole career-wise' and worried 'will I be damned as poacher come gamekeeper' but felt this had not occurred. There are skills required for the scrutiny role that mirror those of chief officers. This scrutiny officer described her role as being a 'relationship manager'. In the newly created scrutiny support role, officers need to provide the same kind of facilitative support to enable non-executive members to fully develop their role. Many scrutiny officers demonstrated a keen awareness of how they have to coach and coax these members and officers to ensure effective scrutiny. In one unitary Labour leader cabinet authority, where party loyalties were strong, the scrutiny officer described his role as 'a lot of negotiation, and work with the members to get them on board and work with us'. Another explained, 'we draft questions and get the theatre of it right'. This choreography is not always well received; in a hung leader cabinet metropolitan authority the scrutiny officer noted: 'there is a them and us against the rest of the world feeling. I thought I was being a critical friend and she thought I was being confrontational'. For officers subject to scrutiny, the challenge from scrutiny can be difficult. In this hung authority the chief executive commented: 
'officers feel challenged by scrutiny and anyone who tells you otherwise is lying'. For the chief executive of a hung alternative arrangement district, however, 'scrutiny was less of a bear pit than the old committees!'.

\section{Emerging communities of meaning}

Some of the anticipated dilemmas associated with political management reform are not widely described as problematic. Role confusion is not reported as problematic in most authorities although there are varying practices and boundaries for action. Depending upon the leadership shown politically and the constitutional arrangements in the authority, officers describe using political antennae to read what space to occupy. Despite the creation of stronger local political executives, officers continue to manage the tension of relating to both local and national political agendas - again using political management skills to engage local politicians with national targets and policies. The shared desire to achieve good results for the area provides an agreed incentive for officers and executive members with the dilemma being how to engage non-executive councillors with this shared corporate agenda. In most authorities, officers report continuing practices relating to serving the whole council and do not feel tensions from being 'two hatted', although in smaller or hung authorities, which lack confident political leadership or separate scrutiny structures, the question of how to serve scrutiny did present early problems. The dilemma described more widely arising from executive decision making is the lack of political skills training for newer officers who no longer attend policy committees to hone their political antennae. Here the importance of the scrutiny function is described in some authorities as a training ground for continuing the tradition of serving the whole council.

The narratives and dilemmas described above reflect individuals' interpretations of the inherited, institutional settings they operate in and how they responded to constitutional change. Some patterning and the development of shared communities of meaning is suggested within and across authorities relating to these institutional settings. Firstly, patterning is clearly related to the political management arrangements and their impact on resources exchanged between officers and councillors. Perhaps the most radical changes are described in the mayoral authorities since these provide far greater political legitimacy and therefore power to the mayor - most notably a separate electoral mandate and much clearer lines of vertical accountability for officers. This can be contrasted to the smaller authorities who still run a streamlined committee system and where relationships between service heads and committee chairs in some cases has remained unchanged.

Most authorities, however, operate as leader cabinet systems and within these settings differences in the constitutional and institutional arrangements also create very different resource flows and role expectations. For example, whether there is individual decision making permitted in the constitution (less likely in Labour authorities) or whether the scrutiny function is supported by scrutiny officers (more likely in Labour and upper tier authorities) creates different expectations of the location of decision making and how political management relationships should work. In the leader cabinet authorities officers in hung authorities appeared to express different narratives of change and dilemmas to those of officers in majority control authorities. In hung authorities, political authority is weakened and officers may be involved in brokering agreement or are able to create policies for executive 'rubber stamping' (Gains 2004a).

Finally, and cutting across each of these variables, personal attributes such as longevity in post and the capability of both politician and officer can create differing and diverse 
dependency relationships. As Lowndes and Wilson summarize, contexts, constitutions and capabilities all play a role in the patterned differences in how local government bureaucratic elites go about their work (Lowndes and Leach 2004).

\section{CONCLUSION}

In conclusion, it is argued that to appreciate the interpreted worlds of senior local government officers it is necessary to take a de-centred approach. In contrast to the powerful committee chairs and professionalized bureaucratic elites of the post war years, the changing context of local governance has created new and increasingly differentiated roles and relationships. Managerialism, and performance and political management reforms to encourage networked local governance, and have altered the rules of the game, the roles played and the resource exchanges in local government. The resulting diverse dependencies between officers and politicians has led to varying and differentiated narratives around the dilemmas of negotiating boundaries, balancing central and local priorities, and how to serve the whole council.

It is argued that these narratives and the dilemmas described are related to the institutional, constitutional, political, and personal resources held by actors. In authorities with stable political control and strong leadership structures, senior officers clearly are working much more closely with a smaller group of leading councillors. As with their Whitehall counterparts, these relationships work best when there is a shared understanding of the political legitimacy of the elected politicians and informatory advantages held by bureaucrats. Overall, however, a cadre of local 'Sir Humphreys' does not appear to be developing. It is argued that this is unlikely given two differences deeply embedded in the traditions of local government and which survive political management reform, that of serving the whole council and that of clearer delegation of decision making.

\section{ACKNOWLEDGEMENT}

The author would like to thank those interviewed who made time to discuss their experiences with her and other members of the ELG research team (for details of the evaluation findings, see http://www.ipeg.org.uk/research/elgnce/index.php). These interviews were undertaken by the author as part of a wider evaluation of the Local Government Act 2000 funded by the UK Department for Communities and Local Government. The author alone takes responsibility for the analysis presented here. At the time of the research, the authorities visited reflected the national picture and included 4 Labour, 3 Conservative, 3 Liberal Democrat and 5 hung authorities; in terms of political management, 10 were leader cabinet, 3 mayoral and 2 alternative arrangement authorities; finally, 4 were metropolitan, 3 county, 4 district and 4 unitary authorities.

\section{REFERENCES}

Ackroyd, S., I. Kirkpatrick and R. Walker. 2007. 'Public Management Reform in the UK and its Consequences for Professional

Organization: A Comparative Analysis', Public Administration, 85, 1, 9-26.

Bevir, M. and R.A.W. Rhodes. 2003. Interpreting British Governance. London: Taylor and Francis.

Bevir, M. and R.A.W. Rhodes. 2006a. 'Interpretive Approaches to British Government and Politics', British Politics, 1, 1, 84-112. Bevir, M. and R.A.W. Rhodes. 2006b. 'Disaggregating Structures as an Agenda for Critical Realism: A Reply to McAnulla',

British Politics, 1, 3, 397-403.

Bevir, M. 2007. 'New Labour in Time', Parliamentary Affairs, 60, 2, 332-40.

Bevir, M. and R.A.W. Rhodes. 2003. Interpreting British Governance. London: Taylor and Francis.

Borraz, O. and P. John. 2004. 'The Transformation of Urban Political Leadership in Western Europe', International Journal of

Urban and Regional Research, 28, 1, 107-20.

Byrne, T. 1992. Local Government in Britain. London: Penguin. 
Chandler, J. 2001. Local Government Today. Manchester: Manchester University Press.

Clarke, K. and F. Gains. 2007. 'Constructing Delivery: Implementation as an Interpreted Process', Critical Policy Analysis, $1,2,133-8$.

Copus, C. 2004. Party Politics and Local Government. Manchester: Manchester University Press.

Denters, B. and L. Rose. 2005. Comparing Local Governance: Trends and Developments. Basingstoke: Palgrave.

Fox, P. and S. Leach. 1999. Officers and Members in the New Democratic Structures. London: Local Government Information Unit.

Finlayson, A. 2004. 'The Interpretive Approach in Political Science: A Symposium', British Journal of Politics and International Relations, 6, 2, 129-64.

Fox, P., M. Lyons and C. Skelcher. 2002. Continuity or Change? Officers and New Council Constitutions. London: ODPM.

Gains, F. 2004a. 'The Local Bureaucrat? A Block to Reform or a Key to Unlocking Change?, in G. Stoker and D. Wilson (eds), Local Government in a New Century. Basingstoke: Palgrave, pp. 91-106.

Gains, F. 2004b. 'Hardware, Software or Network Connection? Theorising Crisis Catalyst in UK Next Steps Agencies', Public Administration, 82, 3, 547-66.

Gains, F. 2007. 'Performance, Party, Partnership or Public: Finding a Focus for Political Leadership', in P. Weller and R. Koch (eds), Public Governance and Leadership. Wiesbaden: DUV.

Green, D. 1981. Power and Party in an English City. London: Allen and Unwin.

Goss, S. 2003. Making Local Government Work. Basingstoke: Palgrave.

Gyford, J. 1976. Local Politcs in Britain. London: Croom Helm.

Gyford, J., S. Leach and C. Game. 1989. The Changing Politics of Local Government. London: Unwin Hyman.

Hay, C. 2004. 'Taking Ideas Seriously in Explanatory Political Science', British Journal of Politics and International Relations, 6, 2, 142-9.

Kerley, R. 1994. Managing in Local Government. Basingstoke: Macmillan.

Laffin, M. 1990, Professionalism in Local Government: Change and Challenge. Harlow: Longman.

Laffin, M. and T. Entwistle. 2000. 'New Problems, Old Professions? The Changing National World of the UK Local Government Professions', Policy and Politics, 28, 2, 207-20.

Leach, S., J. Stewart and K. Walsh. 1994. The Changing Organisation and Management of Local Government. Basingstoke: Macmillan.

Leach, R. and J. Percy-Smith. 2001. Local Government in Britain. Basingstoke: Palgrave.

Lowndes, V. and S. Leach. 2004. 'Understanding Local Political Leadership: Constitutions, Contexts and Capabilities', Local Government Studies, 30, 4, 557-75.

McAnulla, S. 2006. 'Challenging the New Interpretivist Approach: Towards a Critical Realist Alternative, British Politics, 1, 1, 113-38.

Newman, J. 2001. Modernising Governance: New Labour Policy and Society. London: Sage.

ODPM, 2001. (http://www.local-regions.odpm.gov.uk/ncc/guidance/pdf/chap8.pdf).

Pratchett, L. and M. Wingfield. 1994. The Public Service Ethos in Local Government: A Research Report. London: CLD Limited and ICSA.

Rhodes, R.A.W. and P. Dunleavy. 1995. Prime Minister, Cabinet and Core Executive. London: Macmillan.

Rhodes, R.A.W. 1997. Understanding Governance. Buckingham: Open University Press.

Richards, D. 2007. New Labour and the Civil Service: Reconstituting the Westminster Model. Basingstoke: Palgrave.

Richards, D. and M.J. Smith. 2004. 'Interpreting the World of Political Elites', Public Administration, 82, 4, 777-800.

Saunders, P. 1980. Urban Politics: A Sociological Interpretation. Harmondsworth: Penguin.

Skelcher, C. and S. Snape. 2001. Political Executives and the New Ethical Framework. London: DETR.

Smulian, M. 2005. 'Truce in Liverpool Row', Local Government Chronicle, 2 June.

Snape, S., D. Hall, F. Taylor, et al. New Forms of Political Management Arrangements. London: DETR/IdeA.

Snape, S., S. Leach and C. Copus. 2002. The Development of Overview and Scrutiny in Local Government. London: ODPM.

SOLACE. 2005. Managing in a Political Environment. London: Solace.

Stewart, J. and G. Stoker. 1989. The Future of Local Government. Basingstoke: Macmillan.

Stewart, J. 2000. The Nature of British Local Government. Basingstoke: Macmillan.

Stewart, J. 2003. Modernising British Local Government. Basingstoke: Palgrave.

Stoker, G. 2003. Transforming Local Government. Basingstoke: Palgrave.

Stoker, G., F. Gains, A. Harding, et al. 2003. Implementing the 2000 Act with respect to the New Council constitutions and the Ethical Framework (http:/ / www.elgnce.org.uk).

Stoker, G., F. Gains, S. Greasley, et al. 2004. Operating the New Council Constitutions in English Local Authorities: A Process Evaluation.

London: Office of the Deputy Prime Minister (available at http://www.elgnce.org.uk).

Stoker, G., F. Gains, S. Greasley, et al. 2007. The Outcomes and Impacts of the New Council Constitutions. London: CLG.

Sullivan, H. 2007. 'Interpreting “Community Leadership" in English Local Government', Policy and Politics, 35, 1, 141-61.

Sullivan, H. and C. Skelcher. 2002. Working Across Boundaries. Basingstoke: Palgrave. 


\section{FRANCESCA GAINS}

Thain, C. and M. Wright. 1995. The Treasury and Whitehall: The Planning and Control of Public Expenditure 1976-1993. Oxford: The Clarendon Press.

Travers, T., G. Jones and J. Burnham. 1997. The Role of the Local Authority Chief Executive in Local Government. York: York Publishing Services.

Young, K. 1987. Politicians and Professionals: The Changing Management of Local Government. Luton: LGTB.

Weller, P.H. Bakvis and R.A.W. Rhodes. 1997. The Hollow Crown. Basingstoke: Macmillan.

Widdicombe, D. 1986. The Conduct of Local Authority Business: Report of the Committee of Inquiry into the Conduct of Local Authority Business, Cmnd 9797, London: HMSO.

Wilson, D. and C. Game. 1994. Local Government in the United Kingdom. Basingstoke: Macmillan.

Wilson, D. and C. Game. 2007. Local Government in the United Kingdom. Basingstoke: Palgrave.

Yanow, D. 1996. How Does a Policy Mean? Interpreting Policy and Organisational Actions. Washington, DC: Georgetown University Press.

Date received 9 January 2008. Date accepted 12 May 2008. 